\title{
THE RISE AND FALL OF THE “ANTISCORBUTICS”: SOME NOTES ON THE TRADITIONAL CURES FOR "LAND SCURVY"
}

by

\section{R. ELWYN HUGHES *}

\begin{abstract}
"For these have a singular priviledge and prerogative in reason, to pull up this disease by the rootes."

(Wierus, 1622)

"...the simple antiscorbutics so much extolled by Eugalenus, are by no means sufficient to remove it."
\end{abstract}

(Lind, 1753)

The first part of this paper outlines the emergence of the "antiscorbutic" herbs as the basis of standard medications for treatment of scurvy amongst land-dwellers. The second part describes the preparation of five "antiscorbutic" herb preparations reportedly successful in the treatment of a number of cases described as "scurvy" in the late sixteenth and seventeenth centuries. Analyses of their ascorbic acid (vitamin C) content indicates their essential ineffectiveness as a treatment for clinically-defined scurvy (avitaminosis C) and supports the belief that the term "scurvy" was widely used by clinicians to describe a range of conditions unrelated to lack of vitamin $C$.

By the beginning of the seventeenth century the use of lemon juice for the prevention and cure of scurvy (avitaminosis C) amongst seafaring personnel was reasonably well established in Europe. ${ }^{1}$ John Woodall, in his Surgeon's mate (1639), commented that "Succus Limonum, or juice of lemons ... [is] the most precious helpe that ever was

*R. Elwyn Hughes, Ph.D., School of Pure and Applied Biology, University of Wales, Cardiff CF1 3XF.

ACKNOWLEDGEMENTS

Mr John Hurley and Miss Leila Moulay are to be thanked for their valuable assistance in the vitamin C analyses, Mr J. R. Kenyon for guiding me through the National Museum of Wales collection of early herbals, and Mr Ceri Davies of the University of Wales for assistance with the Latin texts. I thank the staffs of the British Library, the Wellcome Institute for the History of Medicine Library, London, the library of the University of Wales College of Medicine, Cardiff and the National Library of Wales, Aberystwyth, for the use of materials held by those libraries.

${ }^{1}$ K. J. Carpenter, The history of scurvy and vitamin C, Cambridge University Press, 1986, pp. 12-28; J. De Zulueta and L. Higueras, 'Health and navigation in the South Seas: the Spanish experience', in J. Watts, E. J. Freeman and W. F. Bynum (eds.), Starving sailors, London, National Maritime Museum, 1981, pp. 85-99; J. Watt, Medical perspectives of some voyages of discovery, Lettsome Lecture 1979, Medical Society of London, 1979. 
discovered against Scurvie to be drunke at all times...".2 It would appear that the prevention and cure of maritime scurvy by lemon juice was extensively practised some time before Lind's classical experiment in the mid-eighteenth century. ${ }^{3}$ And although there are grounds for doubting the efficacy of some of Lind's "preserved" sources of vitamin $\mathrm{C}^{4}$ there can be little doubt that his experimentally-based advocacy of fresh lemon juice placed the seal of scientific approval on what had hitherto been an empirically-based practice.

Our present knowledge of the biochemistry of vitamin $\mathrm{C}$ and of its half-life in the body is consonant with the appearance of scurvy after four to five months at sea and with its cure by the amounts of lemon juice advocated by Lind. ${ }^{5}$ The historical emergence of maritime scurvy was clear and sudden, associated with (and a necessary consequence of) the acquisition by man of skills and knowledge that allowed him to remain at sea for periods of months rather than days. And its demise may be equally clearly delineated. By the early nineteenth century the cure of scurvy amongst sailors was no longer a problem - as witnessed, for example, in 1848 by Turnbull's almost monotonously sucessful treatment of scorbutic sailors arriving at Liverpool simply by providing them each with two lemons daily-a most elegant vindication of Lind's pioneer study. ${ }^{6}$

The story of scurvy amongst non-seafaring people-the so-called "land-scurvy"-, however, follows a somewhat different pattern. When Woodall extolled the virtues of lemon juice as a cure for scurvy at sea, he carefully contrasted its value with that of the traditional "antiscorbutic" plants "namely Scurvy-grasse, Horse reddish roots, Nasturtia Aquatica, Wormwood, Sorrell and many other good meanes" whose value extended, however, "only to the Cure of those which live at home ...". ${ }^{7}$ Lind was later to show that in the previous century Ronsseus (Beaudouin Ronsse) had already made a similar distinction between the use of oranges by seamen on long voyages and the dependence of ordinary land-dwellers on what were to emerge as the traditional antiscorbutics, Cochlearia, Nasturtium, and Beccabunga. ${ }^{8}$

The development of this disparate therapeutic pattern paralleled, and bore a simple conceptual relationship to, the belief that two forms of scurvy existed-sea scurvy and land scurvy. Land scurvy was held to be "cold" and "acid" and thus required "hot" antiscorbutic herbs such as the various members of the Cruciferae as a counteracting agent, whereas sea (or muriatic) scurvy was characterized as "alkaline" and "hot" and could be treated with "cooling" foods and medicines. ${ }^{9}$ Edward Strother was quite clear

2 J. Woodall, The surgeon's mate or military and domestique surgery, London, Bourne, 1639, p. 61.

3 J. Lind, A treatise on the scurvy, 1753, ed. C. P. Stewart and D. Guthrie, Edinburgh University Press, 1953, pp. 145-8.

${ }^{4}$ R. E. Hughes, 'James Lind and the cure of scurvy; an experimental approach', Med. Hist., 1975, 19: $342-51$.

${ }^{5}$ A. F. Hess, Scurvy past and present, Philadelphia and London, Lippincott, 1920, p. 8; Medical Research Council Special Report Series No. 280, Requirements of human adults, London, HMSO, 1953; R. E. Hughes, Vitamin C; some current problems, London, British Nutrition Foundation, 1981.

6 J. Turnbull, 'Observations on scurvy', Lancet, 1848, i: 601-4.

${ }^{7}$ Woodall, op. cit., note 2 above.

${ }^{8}$ Lind, op. cit., note 3 above, p. 264.

${ }^{9}$ It may be noted that belief in the classical humoral theory of disease and in its correction by appropriate dietary therapy persists in many parts of the world. It has been suggested that its prevalence amongst the 


\section{R. Elwyn Hughes}

on this point when he wrote that the "Diet of Scorbuticks is never uniform, but must be govern'd by the Knowledge of the State of Juices then reigning . . ". 10 So too, John Arbuthnot, in his Essay concerning the nature of aliments (1756) in discussing the cure of the "muriatick scurvy", "common among Mariners", advocated the avoidance of "the hot Antiscorbuticks of the Mustard Kind". 11

Lind, in the third chapter of his Treatise, argued convincingly against this assumption that two or more forms of the disease existed. ${ }^{12}$ Nevertheless, the belief that different forms of scurvy existed, with respectively appropriate therapies, persisted for some centuries and is one of the more interesting aspects of the history of the disease. Citrus fruits, the proven remedy for sea scurvy, did not figure prominently in the therapy advocated for "land scurvy", the treatment of which almost invariably included at least one preparation made from the "antiscorbutic" plants.

Authors differed in the list of plants that they placed in the "antiscorbutic" category, but they usually included at least two of what became an established triumvirate, namely, in modern terminology, Cochlearia officinalis (scurvy grass), Veronica beccabunga (brooklime), and Nasturtium officinale (water cress). When exactly these plants attained their established position as antiscorbutics is not clear, but their prominence in herbals and medical writings appears to reflect the recognition of scurvy as a clinical condition.

By the end of the sixteenth century the first printed books dealing specifically with scurvy had appeared. Bothius (Johann Echth) published his De scorbuto in 1541; his yardsticks were the stomacace and the sceletyrbe of Pliny interlaced with general recommendations, but with no specific remedies. ${ }^{13}$ It would appear that the earliest writer on scurvy to deal substantially with the three antiscorbutics was Wierus (Johann Wier) in his influential De scorbuto tractatus (1567). He included an appendix which dealt specifically with Cochlearia. He included Dodonaeus' diagram of the whole plant and also a diagram of the leaves of a young plant in the winter, which suggests that he was anxious that the plant should be correctly recognized. He pointed out that it was not to be confused with Telephium or Britannica. ${ }^{14} \mathrm{He}$ has similar, but not so detailed, accounts of Nasturtium aquaticum (minus and maius) and also of Beccabunga. Subsequent writers on scurvy borrowed extensively, either directly or indirectly, from Wierus and by the middle of the seventeenth century the antiscorbutic trio was an established feature of all works on scurvy.

A necessary consequence of this was that by the end of the century sporadic references to scurvy and to the supposed curative properties of the "antiscorbutics"

more primitive groupings in Peninsular Malaya may be traced to the translation of the early Arabic medical texts into Malay. L. Mandeson, Shared wealth and symbol, Cambridge University Press, 1986, pp. $127-43$.

${ }^{10}$ E. Strother, An essay on sickness and health, London, Rivington, 1752, p. 151.

$11 \mathrm{~J}$. Arbuthnot, An essay concerning the nature of aliments and the choice of them . . , 4th ed., London, Tonson, 1756, p. 154.

${ }_{12}$ Lind, op. cit., note 3 above, pp. 54-63.

$13 \mathrm{~J}$. Echthius, De scorbuto, vel scorbutica passione epitome, reprinted in D. Sennertus, De scorbuto tractatus . . , Wittenberg, J. W. Fincel for Z. Schurer, 1624.

$14 \mathrm{~J}$. Wierus, De scorbuto tractatus, reprinted in D. Sennertus, op. cit., note 13 above; the Library of the Wellcome Institute for the History of Medicine, London holds a copy of an English translation, $A$ discourse of the scorby translated out of Wyers observations, London, Kyngston, 1622. 


\section{The rise and fall of the "antiscorbutics"}

were beginning to appear in the herbals; previous herbals had made no references to the disease and the antiscorbutic plants, when present, were, perforce, treated in a completely non-scorbutic context. For example, the herbals of Fuchs (1542), Bock (1552), and Mattioli (1565) all contained detailed discussions of the virtues of Beccabunga but without reference to any antiscorbutic properties. ${ }^{15}$

William Turner's Herbal (1568) heralded a new era. Turner admitted to a difficulty in distinguishing "brooklyme" from "sea porcelline"- "I dout which of these two I should take for the right Cepea" (Cepea = Veronica beccabunga $)$-and the heavily serrated leaves of his diagram of "brooklyme" underlines his confusion. Nevertheless, his book contained what must be one of the earliest references to scurvy in a British herbal.

... I have proved it my selfe by experience that brooklyme is very good for a decease that reigneth much in Freselad called the Scourbuch. I sod the herbe in butter milke, the cheese and butter taken away, and gave the patientes it so. ${ }^{16}$

-a statement which also implies that scurvy was either comparatively rare or unrecognized in Britain at that time. A few years later, L'Obel and Pena referred to the antiscorbutic powers of the cresses, of scurvy grass and of brooklime; more significantly, and possibly for the first time in a herbal, they linked the three together as a cure for scurvy.

Anagallis aquatica sive Becabunga Germanorum . . . adversam indigenam morbii illic Scorbutum noncupatu, quam iuvat, non secus atque Cochlearia, Cardamine aquatica sive Berula $\&$ aliae quas alibi diximus $\ldots .{ }^{17}$

Henry Lyte's $A$ niewe herbal (translated from de l'Ecluse's French version of Rembert Dodoens's Cruydeboeck) in 1578 presented a more fragmentary treatment; "Brooklime", "Water cresses", and "Spooneworte" (Cochlearia) were adequately discussed but the latter alone was held to have an antiscorbutic virtue: "Spooneworte ... is also a singular remedie against the disease of the mouth ... called by the Hollanders and Friselanders Scuerbuyck, against whiche evill it hath bene lately proved to be very good and is in great estimation and much used of the Hollanders and Frieseans." 18

In 1583 Dodoens published his magnum opus, Stirpium Historiae. By now all three herbs were held to be clearly antiscorbutic; of water cress Dodoens wrote, "ad stomacacem, quam Germani Schorbuch \& Schoosbuyck nuncupant, in vino aut lacte decoctum" and there is a similar assessment of brooklime. ${ }^{19}$ Scurvy grass is now

\footnotetext{
${ }^{15}$ Leonhard Fuchs, De historia stirpium . . . Basle, Off. Isingriniana, 1542, p. 724; Hieronymus Bock, De stirpium, maxime earum, quae in Germania nostra nascuntur, Strassburg, W. Richel, 1552, pp. 81, 187; Pietro Andrea Mattioli, Commentarii in sex libros Pedacii Dioscoridis Anazarbei de materia medica ...., Venice, V. Valgrisius, 1565, p. 621.

${ }_{16} \mathrm{~W}$. Turner, The first and second parts of the herbal . . , London, Birckman, 1568, p. 123.

${ }_{17}$ Petrus Pena and Matthias de L'Obel, Stirpium adverseria nova . . . , London, T. Purfoot, 1571, p. 195.

${ }^{18} \mathrm{R}$. Dodoens, A niewe herball or historie of plantes . . . translated out of French into English, by Henry Lyte, Antwerp, Dewes, 1578, pp. 117-18.

${ }^{19}$ Idem, Stirpium historiae pemptades sex, Antwerp, C. Plantin, 1583, pp. 581-4.
} 
presented primarily as an antiscorbutic agent ("Malo, quod Scorbuck Germania nuncupat, efficaciter medetur, in lacte aut vino decocta ...") and there is a revealing reference to the apparently recent emergence of scurvy grass as a plant of medical significance ("veteribus ni fallor incognita"). ${ }^{20}$ Gerard, whose herbal was largely a re-presentation of Dodonaeus' Stirpium historiae, added nothing new about the antiscorbutics. $^{21}$

An important factor in the ascendancy of the "antiscorbutics" would appear to be the increased need for official remedies elicited by an apparently sudden and puzzling increase of a condition described as scurvy amongst the non-seafaring population of Britain in the first half of the seventeenth century. The evidence for this is substantial. Marchmont Nedham, in his Medela medicinae (1665), had no doubt that scurvy was on the increase and in support of his thesis quoted the increase in the Bills of Mortality deaths from scurvy, from 5 in 1630 to over 100 in 1656. Nedham argued that scurvy had changed its form "from what it was in former days, and become every jot as Universal . . ."22 So too Gideon Harvey, who commented in 1675 that

Many years it [scurvy] remained on that Coast [i.e., Holland] before we were sensible of it here in England: for there are many Physicians yet living who in the former part of their Practice had not so much as heard of the Name of this Disease, whereas within the last 20 or 30 years past it's grown very familiar among us. ${ }^{23}$

His remarks were echoed in Daniel Sennert's Practical physick (1676): "As for the Scurvey 'tis become Endemious amongst us ...". ${ }^{24}$ There is confirmatory evidence that in Wales, too, scurvy was regarded as a new disease at the beginning of the seventeenth century. (Sir) Thomas Wiliems of Trefriw, a priest and practising physician, compiled the manuscript for his projected Thesaurus Linguae Latinae et Cambrobritannicae in the years 1604 to 1607 . His entry for the word "Britanica" is revealing:

Britanica, plin. herba est foliis oblongis et nigris radice item nigra, nervis et dentibus salutaris, et contra Anginas et serpenturam morsus, efficax remedium habens. Gwyr dyscedic yr oes honn sy'n coeliaw mai'r lhyseun yma ywr Cochlearia, y lhwylys sydh mor odidoc y iachau'r scorbut, clevyt newydh yn ein gwlad ni Cymru. ${ }^{25}$

It is, however, difficult to accept that these reports reflected a real increase in the incidence of true clinical scurvy (i.e., avitaminosis C) in Britain, particularly as there is

${ }^{20}$ Ibid., p. 583.

${ }^{21}$ John Gerard, The herball or, generall historie of plantes, [enlarged by Thomas Johnson], London, Islip, Norton, and Whitakers, 1633, pp. 401-2.

${ }_{22}$ M. N. [Marchmont Nedham], Medela medicinae; a plea for the free profession and a renovation of the art of physick, London, Loundes, 1665 , p. 38.

${ }^{23} \mathrm{G}$. Harvey, The disease of London or a new discovery of the scorvey, London, James, 1675, p. 211.

${ }^{24} \mathrm{D}$. Sennert, Practical physick or five distinct treatises of the most predominant diseases of these times. In English by H. Care, London, Whitwood, 1676, sig. A7.

${ }^{25}$ Aberystwyth, National Library of Wales, MS Peniarth 228. The translation of the Welsh is: "Learned men of this age believe that this plant is the Cochlearia, the spoonwort which is so excellent to cure the scorbute, a new disease in our country, Wales." I am indebted to Professor J. E. Caerwyn Williams, F.B.A. for details of this entry and for providing me with a transcript of it. Thomas Wiliems repeats his 


\section{The rise and fall of the "antiscorbutics"}

no evidence of any correspondingly sudden dietary changes during the same period. It is possible, but unlikely, that they represented improved diagnosis of an already existent condition; but the most probable explanation is that scurvy or "the scorbute" suddenly became a convenient nosological safety net for the not inconsiderable diagnostic failures of the period - a practice that apparently continued well into the eighteenth century and beyond.

It is yet a suficient Answer to Patients when they enquire into their ailments to give this Return to a troublesome Enquirer, that their Disease is the Scurvy, they rest satisfied that they are devoured with a Complication of bad Symptoms....

wrote Edward Strother in $1725 ;^{26}$ and at the end of the century Sir John Hill placed on the title page of his The power of the water dock against the scurvy a quotation from Mattioli, "If any one is ill, and knows not his Disease, Let him suspect the Scurvy."27

Whatever the true explanation, there can be little doubt that reports of conditions described as scurvy increased considerably during the seventeenth century. Correspondingly, the use of the antiscorbutics in preparations for the treatment of such conditions received a fresh impetus. Their reputation was considerably enhanced and by the end of the century they were firmly established in the medical and herbal literature. John Ray was so convinced of the therapeutic efficacy of the antiscorbutics that he regarded their distribution, and in particular, the occurrence of Cochlearia in scurvy-afflicted areas, as Providential and included this as an argument in his natural theology compilation The wisdom of God manifested in the works of the Creation:

... there are, by the wise Disposition of Providence, such Species of Plants produced in every County as are most proper and convenient for the Meat and Medicine of the Men and Animals that are bred and inhabit there. Insomuch that Solenander writes that from the frequency of the Plants that sprung up naturally in any region he could easily gather what endemial Diseases the Inhabitants thereof were subject to; So in Denmark, Friesland and Holland, where the Scurvy usually reigns, the proper Remedy thereof, Scurvy-grass does plentifully grow. ${ }^{28}$

Predictably, there are available a substantial number of reports describing the use of preparations of the antiscorbutic herbs for the cure of "scurvy". Clinically defined scurvy (avitaminosis C) however, would be curable only by preparations containing an adequate amount of ascorbic acid (vitamin $\mathbf{C}$ ). An examination of the vitamin $\mathbf{C}$ content of these "successful" antiscorbutic preparations by providing information about the potential usefulness of the antiscorbutic herbs in the treatment of scurvy

\footnotetext{
comment under his entry for Cochlearia, which reads: "lhwylys rhagorol y iachau'r scorbut-clefyt newydd" ("spoonwort excellent for the cure of the scorbute-a new disease").

${ }^{26}$ Strother, op. cit., note 10 above, p. 150.

$27 \mathrm{~J}$. Hill, The power of water-dock against the scurvy, 10th ed., London, 1777. Note also Russell's comment, "It is hard to say what exactly is meant by the Scurvy amongst the physicians of this Age, for all diseases of the skin are distinguished by this Name because it sounds better in the Ears of the delicate than the Itch, Leprosy or the King's Evil": R. Russell, Dissertation on the use of sea-water in ...the scurvy, London, 1760 , p. 158. See also Carpenter, op. cit., note 1 above, p. 56.

$28 \mathrm{~J}$. Ray, The wisdom of God manifested in the works of the Creation, 6th ed., London, Innys, 1714, p. 114.
} 


\section{R. Elwyn Hughes}

would indicate whether the conditions successfully treated were in fact cases of true scurvy.

THE VITAMIN C CONTENT OF ANTISCORBUTICS AND MEDICINES PREPARED FROM THEM

Its popular English name (scurvy grass) has alone ensured that Cochlearia has pride of place amongst the antiscorbutic herbs and the reports from different parts of the world of the empirical discovery of its therapeutic virtue by scorbutic sailors on reaching terra firma are familiar features of the folk-lore of scurvy. Cook's journals of the voyages of the Endeavour and of the Resolution and the Discovery, from 1776 to 1780 , reveal his almost pathological preoccupation with gathering large amounts of what he regarded (not always correctly) as scurvy grass whenever a landing provided an opportunity for this. And the antiscorbutics provided the basis of a wide range of antiscorbutic extracts, syrups, and juices until well into the nineteenth century.

It is now an established scientific fact that scurvy (avitaminosis $\mathrm{C}$ ) results from a failure to ingest adequate amounts of vitamin $\mathrm{C}$ (ascorbic acid); the body stores of the vitamin will last for some weeks after which period, unless there is an intake of ascorbic acid, scurvy inexorably develops. A daily intake of as little as $10 \mathrm{mg}$ will prevent the emergence of frank scurvy but the recommended daily allowance (RDA) in the United Kingdom is currently set at $30 \mathrm{mg} .{ }^{29}$ Vitamin $\mathrm{C}$ is present primarily in plants and the usual dietary sources are citrus fruits, leafy vegetables, and potatoes.

Table: THE ASCORBIC ACID (VITAMIN C) CONTENT OF FOLIAGE OF REPRESENTATIVE PLANTS

$\mathrm{Mg} / 100 \mathrm{~g}$ fresh weight.* Mean values with standard errors of means; the figures in brackets denote the number of samples analysed.

\begin{tabular}{|c|c|}
\hline $\begin{array}{l}\text { Means of } 213 \text { Angiosperm species } \\
\text { Mean of } 41 \text { woody species }\end{array}$ & $\begin{array}{l}162 \pm 8 \\
293 \pm 27\end{array}$ \\
\hline $\begin{array}{l}\text { "Vitamin C-rich" species } \\
\text { Primula vulgaris Huds. (primrose) } \\
\text { Malus domestica Borkh. (apple) } \\
\text { Erica tetralix L. (bog heather) } \\
\text { Vicia cracca L. (tufted vetch) }\end{array}$ & $\begin{array}{l}805 \pm 48 \\
496 \pm 28 \\
394 \pm 21 \\
349 \pm 15\end{array}$ \\
\hline $\begin{array}{l}\text { The "antiscorbutics" } \\
\text { Cochlearia officinalis L. (scurvy grass) } \\
\text { Nasturtium officinale R. Br. (water cress) } \\
\text { Veronica beccabunga L. (brooklime) }\end{array}$ & $\begin{array}{l}63 \pm 12 \\
83 \pm 4 \\
46 \pm 10\end{array}$ \\
\hline $\begin{array}{l}\text { Others** } \\
\text { Galium aparine L. (goosegrass) } \\
\text { Menyanthes trifoliata L. (buckbean) } \\
\text { Urtica dioica } \text { L. (stinging nettle) }\end{array}$ & $\begin{aligned} 84 & \pm 6 \\
74 & \pm 9 \\
169 & \pm 14\end{aligned}$ \\
\hline
\end{tabular}

*Based (with some additions) on E. Jones and R. E. Hughes, op. cit., note 31.

**These are representative "popular remedies" favoured by, e.g., Hugh Davies in his Welsh botanology (1813) and John Wesley in his Primitive physic, 23rd ed., (1791).

${ }^{29}$ See, e.g., Hughes, op. cit., note 5 above; T. K. Basu and C. J. Schorah, Vitamin $C$ in health and disease, London and Canberra, Croome Helme, 1982. 
The anti-scorbutic (scurvy-preventing or -curing) powers of any plant or plant preparation will therefore be a direct reflection of its content of vitamin $\mathrm{C}$. And the three antiscorbutics score poorly in this respect (see table).

Scurvy grass itself is a comparatively poor source of vitamin $\mathrm{C}$. The reported mean vitamin $\mathrm{C}$ content of $100 \mathrm{~g}$ of the fresh leaves is within the range $50-85 \mathrm{mg}$ with a mean value of 63 . This is little more than a third of the mean value for 213 Angiosperm species analysed and only a fifth of the mean value of 41 woody (trees and shrubs) species analysed (table). Had the scorbutic sailors who discovered the "virtues" of scurvy grass deliberately set out to select a plant low in ascorbic acid, they could scarcely have done better. ${ }^{30}$ Samples of Primula vulgaris (primrose), taken on Sully Island on the south Glamorgan coast of Wales contained over ten times as much vitamin $\mathrm{C}$ as scurvy grass from a neighbouring site. ${ }^{31}$

Certainly raw scurvy grass (or the leaves of virtually any other known Angiosperm for that matter), if taken in sufficient quantities, could provide sufficient vitamin $C$ to protect against scurvy. However, a daily intake of $30 \mathrm{mg}$ (the RDA) would require the daily consumption of some two ounces of stalk-free leaves-or, for a ship with a complement of 100 (as in James Cook's celebrated voyages), some $80 \mathrm{lbs}$ of leaf weekly - a not insubstantial amount of a plant not always easily available and with a comparatively short half-life in the picked form. Whether or not scurvy grass made an important contribution to the prevention of scurvy on Cook's voyages is difficult to determine as Cook provided his crew with such a wide range of vegetables and fruit.

But it was in the preparations of the herbalists and the medical practioners that the antiscorbutics were most widely used. By the mid-seventeenth century a wide range of preparations was available for the treatment of scurvy, by then, as indicated above, held to be of widespread occurrence. The medical texts of the period are replete with accounts of successful cures of scurvy but a simple inspection of many of them reveals that they could in no way have effected a cure as they must have been completely devoid of any vitamin $\mathrm{C}$. This is true of a large proportion of the "cures" reported by John Hall in 1657, for example his use of preparations based on snail water and frog spawn water to treat a female patient. ${ }^{32}$ Similarly impossible "cures" were recorded by William Salmon in 1687 and by Martin Lister in 1696. ${ }^{33}$

Somewhat more plausible are the many preparations based on the antiscorbutic triumvirate-scurvy grass, brooklime, and water cress. In the notes that follow, the

\footnotetext{
30 There is some evidence that maritime plants are in general poorer sources of vitamin $\mathrm{C}$ than non-maritime ones. The mean vitamin $\mathrm{C}$ concentration of eleven species of halophytes analysed was $78.0 \mathrm{mg} / 100 \mathrm{~g}$ - considerably lower than the overall value of 213 for Angiosperms in general. This information was kindly supplied by Dr P. Adam of the School of Botany at the University of New South Wales.

${ }^{31}$ Eleri Jones and R. E. Hughes, 'Foliar ascorbic acid in some Angiosperms', Phytochemistry, 1983, 22: 2493-9, 23: 2366-7. The belief that scurvy grass is a potent source of vitamin $C$ is a peculiarly persistent one; in 1987 a reviewer described it as "perhaps the single richest source, by weight, of ascorbic acid to be found in nature" (A. S. Verdesca, New Engl. J. Med., 1987, 310: 224).

${ }^{32}$ H. Joseph, Shakespeare's son-in-law; John Hall, man and physician, Hamden, Conn., Archon, 1964, p. 112.

${ }^{33} \mathrm{~W}$. Salmon, Select physical and chyrurgical observations ... and cures, London, T. Passinger and J. Richardson, 1687, pp. 323-31; M. Lister, Sex exercitationes medicinales . . , Frankfurt, 1696, p. 190.
} 


\section{R. Elwyn Hughes}

vitamin $\mathbf{C}$ (ascorbic acid) content is recorded for five of the traditional and most widely-used of the "antiscorbutic" preparations prepared as described by three physicians who reported using them (or who claimed knowledge of their use) in the successful treatment of scurvy in the late sixteenth and early seventeenth century.

John Hall described the treatment of some twelve cases of scurvy in his Select observations upon English bodies (1657); ${ }^{34}$ William Clowes described the cure of two scurvy-stricken sailors in his $A$ profitable and necessarie booke of observations (1596); ${ }^{35}$ and Gwilym Puw (Pue) o'r Creuddyn, a Catholic recusant who combined the professions of soldier, physician, and priest, compiled in 1656 his unpublished manuscript 'A traetice of the Scorbut'. ${ }^{36}$ All three used more or less the same traditional preparations, based on one or more of the three antiscorbutic herbs; Clowes and Puw were strongly influenced by the writings of Wierus.

There is some difficulty in quantifying the somewhat imprecise instructions of the seventeenth century, e.g., in determining what exactly constituted a "handful" of scurvy grass or of brooklime, but in general the preparative instructions were followed as closely as possible. Ascorbic acid (vitamin C) was extracted from the various preparations with 10 per cent metaphosphoric acid and determined by spectrophotometric adaptation of the indophenol dye method. ${ }^{37}$

Juice of brooklime or of scurvy grass (succus cochlearia)

This was frequently used in the treatment of scurvy, sometimes in the "raw" form and sometimes after conversion into a more elaborate preparation. It was usually produced by simple expression of the juice in a mortar. "[H]ae virides in mortario lapideo cum pistillo ligneo condundentur experimentura" were Wierus's instructions, which Puw adapted as "These Hearbes Green Must Bee Beaten in a Mortar-with a wooden pestle, Then strained."38 Using this method of preparation, $100 \mathrm{ml}$ of juice were obtained from $140 \mathrm{~g}$ of fresh foliage of scurvy grass.

The vitamin $C$ content of juice so prepared was $1.2 \mathrm{mg}$ per $100 \mathrm{ml}$ and for a corresponding sample of brooklime juice the value was 1.0 ; these values indicate an almost complete loss of vitamin $\mathrm{C}$ during the preparation of the juice (cf. table). This loss presumably occurred because of oxidation of the ascorbic acid on exposure to atmospheric oxygen and would be enhanced by contact with the enzyme ascorbic acid oxidase which is of widespread distribution in the plant kingdom and would be liberated on maceration of the tissues. The presence of the enzyme was confirmed in

\footnotetext{
34 Reprinted in Joseph, op. cit., note 32 above.

${ }^{35} \mathrm{~W}$. Clowes, A profitable and necessarie booke of observations, 1596, reprinted, ed. D. W. T. Starnes and C. D. Leake, New York, Scholar, 1945.

${ }^{36}$ W. Pue, (Gwilym Puw) (1675) 'De sceletyrrbe vel stomacace or A traetice of the Scorbut', National Library of Wales, 13167B (Llanover E5), pp. 583-624.

${ }^{37} \mathrm{O}$. A. Bessey, 'A method for the determination of small quantities of ascorbic acid and dehydroascorbic acid in turbid and colored solutions in the presence of other reducing substances', J. biol. Chem., 1938, 126: 771-84. This method, as used in the current study, measured only ascorbic acid (vitamin C); dehydroascorbic acid (the oxidized form) has some antiscorbutic activity but it exists in nature only in small amounts and as its half-life at $37^{\circ} \mathrm{C}$ and $\mathrm{pH} 7.4$ is only 5 minutes it was adjudged to be absent from the medications examined. See Eleri Jones, J. E. W. Davies, and R. E. Hughes, 'Tissue ascorbic acid and a liver dehydroascorbatase in guinea-pigs', Experientia, 1979, 35: 303-4.

${ }^{38}$ Pue, op. cit., note 36 above, p. 589.
} 


\section{The rise and fall of the "antiscorbutics"}

a supplementary experiment where the loss of vitamin $\mathrm{C}$ from $100 \mathrm{ml}$ of a buffered solution ( $\mathrm{pH} \mathrm{7.0)}$ was more than doubled on addition of $5 \mathrm{ml}$ of the scurvy-grass juice.

Expressed juices of antiscorbutic plants thus lose almost all of their vitamin C within a matter of minutes of preparation and would be of little value in the treatment of scurvy. Eugalenus (1658) and Thomas Willis (1682) were among the strongest advocates of the use of the antiscorbutic juices in the treatment of scurvy ${ }^{39}$ but their advocacy could in no way have been based on practical experience of the successful treatment of scurvy. By the same token, any preparations made from the expressed juices would have been equally ineffective.

\section{Syrup Foresti ('Forestus, his syrup'; 'syr. sceletyrb. Foresti')}

This was prepared as described by Sennert in his Practical physick (1624): 40 "Take the juice of Scurvygrass and Brooklime of each three pints with two pounds of the best sugar, boil them together according to Art and make a syrup." The syrup was accordingly prepared by boiling $7 \mathrm{ml}$ scurvy grass juice with $7 \mathrm{ml}$ brooklime juice and $3.74 \mathrm{~g}$ sugar. The brown colour of the resulting syrup made subsequent analysis difficult but no vitamin $\mathrm{C}$ could be detected (and in the light of the results outlined above, none would be expected). This syrup was widely used in the seventeenth and eighteenth centuries for the treatment (and reported cure) of scurvy. Puw referred to it and Willis included a number of similarly-constituted syrups in his Tractatus ...de scorbuto (1682); they would all have been equally ineffective against the scurvy.

\section{Scorbutick beer}

Hall successfully treated the Countess of Northampton and other scorbutic sufferers using this preparation. ${ }^{41}$ A sample was prepared to accord with Hall's instructions, by boiling $2.1 \mathrm{~g}$ scurvy grass, $1.2 \mathrm{~g}$ water cress, $1.1 \mathrm{~g}$ brooklime, $0.5 \mathrm{~g}$ speedwell and $0.5 \mathrm{~g}$ fumitory leaves with $500 \mathrm{ml}$ freshly brewed beer ${ }^{42}$ until the volume was reduced to $400 \mathrm{ml}$. A muslin bag containing mace, aniseed, and fennel seed was suspended in the preparation until it had cooled. The vitamin $C$ content was measured as indicated above and none was found to be present.

\section{Water against the scurvy}

This was another remedy used by Hall. Two grams of sarsparilla root were placed in $500 \mathrm{ml}$ water and left for 12 hours. Scurvy grass $(3.3 \mathrm{~g})$, brooklime $(1.7 \mathrm{~g})$, and water cress $(1.7 \mathrm{~g})$ were added, together with a few currants, and the mixture boiled until the volume was reduced to $335 \mathrm{ml}$. The vitamin $\mathrm{C}$ content was determined; no vitamin $\mathrm{C}$ was present.

\section{Scurvy-grass beer}

This was used by William Clowes (1596) in the successful treatment of two sailors

\footnotetext{
${ }^{39}$ Severinus Eugalenus, De morbo scorbuto..., The Hague, 1658, e.g., pp. 67, 68, 141, 331; T. Willis, Opera omnia ..., 1682, Amsterdam, p. 125.

${ }^{40}$ Sennert , op. cit., note 24 above, p. 29. See also J. Perrot, 'Note sur l'origine du syrop antiscorbutique', Bul. Sci. pharmac., 1921, 28: 64-6.

41 Joseph, op. cit., note 32 above, p. 3.

42 The sample of freshly-brewed beer was kindly supplied by Brains Brewery, Cardiff.
} 


\section{R. Elwyn Hughes}

suffering from scurvy. A sample was prepared as described by Clowes by bruising $60 \mathrm{~g}$ scurvy grass (vitamin $\mathrm{C}$ content, $42 \mathrm{mg}$ ) in a mortar and adding $250 \mathrm{ml}$ beer. A small bag containing cinnamon, pepper, and ginger was suspended in the preparation which was then left for 2 days. It was found to contain $5.30 \mathrm{mg}$ vitamin $\mathrm{C}$, which had decreased to $3.63 \mathrm{mg}$ a week later. A patient drinking a litre of Clowe's freshly-prepared scurvy-grass beer daily would receive just over $20 \mathrm{mg}$ of the vitamin, which would possibly be just sufficient to cure him/her of scurvy.

Thus, of the five remedies examined only one-the scurvy-grass beer-contained measurable amounts of vitamin $\mathrm{C}$, and even here some 80 per cent of the original vitamin $\mathrm{C}$ content was lost during preparation of the sample. In the light of our current knowledge of the stability of vitamin $\mathrm{C}$ these results are not unexpected. Vitamin $\mathrm{C}$ is a highly labile and easily oxidizable molecule. Boiling at a non-acid pH rapidly destroys it. The preparation of scurvy-grass beeer, which retained some of its vitamin $\mathrm{C}$, did not involve a boiling stage; again, certain plant "secondary metabolites" such as the tannins, are known to preserve vitamin $\mathrm{C}$ against oxidation breakdown ${ }^{43}$ and it is probable that the tannin content of the beer had a protective role in this respect. In general, however, fermented drinks would not be expected to contain substantial amounts of vitamin $C$ despite the promotion of their antiscorbutic efficacy in medical texts. ${ }^{44}$

The widespread advocacy of preparations of the antiscorbutic herbs in the seventeenth and eighteenth centuries may be contrasted with the comparative neglect of lemon and orange juice as antiscorbtics, and this despite their long-established and successful use of the latter in the treatment of scurvy at sea. Expressed lemon juice still contains about half of its vitamin $\mathrm{C}$ content a week after its preparation, in contrast to the juice of scurvy grass and brooklime, from which virtually all the vitamin $\mathrm{C}$ is lost on preparation. 45

Variations of the "antiscorbutic" preparations appeared in the formularies, both official and unofficial, for some time. The "Cerevisia Scorbutica Extemporanea" and the "Succi Scorbutici", described by Quincy in 1730, were little more than modifications of the sixteenth-century formulations. ${ }^{46}$ Interestingly, by the eighteenth century orange juice was advocated as an additional component, a point

\footnotetext{
${ }^{43}$ R. E. Hughes and L. Moulay, unpublished observations.

${ }^{44}$ See, e.g., E. M. Delf, Studies in experimental scurvy-with special reference to the antiscorbutic properties of some South African foodstuffs, Publ. 14, S. Afr. Inst. Med. Res., 1921; F. W. Fox and W. Stone, 'The antiscorbutic value of Kaffir beer', S. Afr. J. med. Sci., 1938, 3: 7-14; Hughes, op. cit., note 4 above. I am indebted to Professor Kenneth Carpenter for drawing my attention to the two South African studies.

${ }^{45}$ The vitamin $\mathrm{C}$ content of a sample of lemon juice ( $\left.\mathrm{pH} 1.6\right)$ decreased from $56 \mathrm{mg} / 100 \mathrm{ml}$ to $22 \mathrm{mg} / 100 \mathrm{ml}$ after 7 days (a retention of 39 per cent); the corresponding values of fresh orange juice ( $\mathrm{pH}$ 2.9) were 35 initially and 18 after 7 days (a retention of 51 per cent): R. E. Hughes, unpublished work. The retention of the vitamin $C$ in the citrus juices is in clear contrast with the almost immediate loss from the juices of the antiscorbutic herbs and may be attributed to (i) a greater initial concentration of vitamin C, (ii) greater acidity, and (iii) the presence in citrus fruit juices of such vitamin C-protective compounds as bioflavonoids.

46 J. Quincy, Pharmacopoeia officinalis \& extemporanea . . . London, Osborn \& Longman, 1730, pp. 547, 574.
} 
underlined by Thornton eighty years later when he wrote that the "orange juice is an excellent assistant to the scurvy-grass, and other acrid antiscorbutics, which, when thus mixed, have been found by experience to produce much better effects than when employed by themselves." 47 By this time, however, the reputation of the antiscorbutics was on the wane. Of Veronica beccabunga Thompson's London Dispensatory pronounced in 1811, "Although brook-lime was formerly considered a good antiscorbutic, yet it is properly disregarded by modern practitioners." 48 In 1820 Hall pointed out that "Three most distinguished writers (Bateman, Blane and Heberden) had separately opined that 'Scorbutus or Scurvy' is now unknown in London, or nearly." ${ }^{49}$ The demise of the antiscorbutics followed soon afterwards and coincided with the official acknowledgement that "Scorbutus ... pellagra ... beri beri ... when they occur in England appear only sporadically". 50

The three "antiscorbutics" that reigned unchallenged in the herbals and pharmaceutical compilations for some two centuries are amongst the least rich Angiosperm sources of vitamin $C$, and their vitamin $C$ content is completely destroyed in the preparation both of their juices and of the other traditional forms in which they were administered. By the same token, "scorbutic" patients successfully cured by practitioners using these treatments could not in reality have been suffering from true scurvy. Carpenter has succinctly summarized the rise and fall of "land scurvy" in Britain and has indicated that when it occurred after 1800 this was either a result of a significant shift in the dietary pattern (with the potato content as the main determinant) or of defective dietary planning and distribution on an institutional scale, as in the outbreaks of the disease in prisons and hospitals. ${ }^{51} \mathrm{He}$ reminds us that in 1820 Hall raised the question whether the earlier widespread reports of "scorbutus" referred in fact to the same disease. ${ }^{52}$

The results of the analyses reported in this paper, coupled with the doubts expressed by some practitioners from the period, support these opinions and force one to the conclusion that clinically-defined scurvy amongst the land population in Britain in the sixteenth and seventeenth centuries was probably a much less common disease than a reading of contemporary medical texts would sometimes lead us to believe. By the same token "scurvy" became one of the most widely-misused of all medical terms.

\footnotetext{
${ }^{47}$ R. J. Thornton, A new family herbal, London, Phillips, 1810, p. 609. Thornton's observation that orange juice "enhanced" the curative powers of the antiscorbutic herbs suggests that someone, at some time, had compared the two in the treatment of "true" scurvy, i.e., avitaminosis C. The finding was not a new one. Lind had pointed out in 1753 that "the scurvy grass, cresses and other acrid alcalescent plants . . . become much more antiscorbutic by the addition of lemon juice, oranges ... " (Lind, op. cit., note 3 above, p. 223) and Sydenham had, in the previous century, advocated adding a generous portion of fresh orange juice to his "antiscorbutic drink" (W. Salmon, Dr Sydenham's practice of physick, London, Smith and Walford, 1695, pp. 165-8).

${ }^{48}$ A. T. Thomson, The London dispensatory, London, Longman, 1811, p. 399.

${ }^{49} \mathrm{M}$. Hall, 'On the acceptance of the term scorbutus and on the prevalency of the disease at different periods', Edinb. med. surg. J., 1820, 16: $204-9$.

${ }^{50}$ First annual report of the Registrar-General of births, deaths and marriages in England, 1839, p. 95; see also Carpenter , op. cit., note 1 above, p. 98.

51 Ibid., pp. 98-132.

52 Ibid., pp. 238-9.
} 


\section{R. Elwyn Hughes}

The position and status of the three "antiscorbutic herbs" are of interest in this respect. It would appear that their entry into, and retention by, the medical literature, was a reflection as much of a priori influences related to early thoughts on the nature of "land scurvy" as of any genuine therapeutic value based on observation. 